\title{
Challenges of Reducing Fresh Produce Waste in Europe-From Farm to Fork
}

\section{Michael Blanke}

INRES- Horticultural Science, University of Bonn, Auf dem Hügel 6, D-53121 Bonn, Germany; E-Mail:mmblanke@uni-bonn.de.

Academic Editor: Les Copeland

Received: 15 April 2015 / Accepted: 23 June 2015 / Published: 30 June 2015

\begin{abstract}
This concept paper summarizes key "hotspots" for waste generation along the food supply chain and identifies a range of existing solutions/measures that can help producers, retailers and consumers reduce the amount of food that is wasted. The majority of food waste of 71-92 kg/head/year in Western Europe was found to originate from private households $(61 \%)$, followed by restaurants and canteens $(17 \%)$ and then supermarkets (5\%); 59\%-65\% (of this food waste $(71-92 \mathrm{~kg}$ ) can be avoided and 54\% thereof are fruit and vegetables. Since ethylene accelerates fruit ripening and its accumulation can lead to fruit decay and waste and new portable instruments now enable continuous in-situ determination of ethylene along the food chain, there is a possible key to reducing food waste of perishable, fresh produce. Hence, suggested countermeasures at the field level are use of ethylene inhibitors (AVG as "Retain" or MCP as "Harvista"), the former prevents pre-mature fruit drop in pome fruit, incentives for processing fruit of industrial grade and whole crop purchase ("WCP"). Along the supply chain, applications of ethylene inhibitors (e.g., 1-MCP as "SmartFresh") absorber strips (e.g., "It's Fresh", Sensitech), bags (e.g., "Peakfresh") as well as simply cooling and venting, and shading to avoid sun exposure. Countermeasures also include superstores no longer promoting multi-packs, e.g., "two strawberry punnets for the price of one", abandon the "Display until" or "Sell by" date, conservative consumer shopping behavior, and sale of class II produce ("Wunderlinge" in Billa or "Kleine Äpfel" in REWE, "Ünique" in Coop), collection (rather than wasting) of perishable food by volunteers ("Die Tafel"), or "Food Sharing" of private household left-over perishable on social media, or any combination of the above to aid reducing fresh produce waste.
\end{abstract}


Keywords: apple; ethylene scrubber; food bank; food sharing; greenhouse gas emissions (GHG); resource conservation; Russian trade embargo; strawberry; sustainability; waste; whole crop purchase

\section{Introduction-Fresh Produce Left in the Field}

Horticulture can be distinguished from agriculture and characterized by producing predominantly fresh, perishable produce, fuelling criticism of waste of perishable food. Waste assessment and reduction have hence long been essential prerequisites of sustainable horticulture. The horticultural sector in Europe is driven by a combination of surplus production, e.g., 1-2 million tonnes apples/year (Blanke, 2007 [1]) and stringent EU marketing standards (VO EU No. 543/2011) even before the Russian fresh food embargo was imposed in August 2014 and the rise of the Polish apple production. The EU standards exclude "under-sized", "mal-formed" and "unevenly colored" produce, e.g., apple, banana or tomato or pepper fruit from being marketed as fresh fruit and are primarily based on cosmetic appearance rather than nutritional value. As a consequence, some fruit and vegetables are not harvested or disposed of after harvest. Fortunately, in many cases such as apples, industrial grade fruit ("cull") go into juicing and processing, In other crops like lettuce, where this is not possible, the crop is ploughed (wasted), if the wholesale market drops, e.g., well below 10 cents per lettuce head during the peak season.

The objective of this invited contribution is to provide a brief overview on fruit and vegetable waste in Western Europe, to incorporate published reports with those unavailable in English and unpublished information (congress lectures with subsequent discussion) as a basis for discussion on the subject within and outside Western Europe. This concept paper is to summarize key "hotspots" for waste generation along the food supply chain and identifies a range of existing solutions/measures that can help producers, retailers and consumers reduce the amount of food that is wasted.

\section{Volumes of Fresh Produce Waste and Associated Financial Losses}

The volume of fresh produce waste in many Western European countries seems to fall within a narrow range with values from $71 \mathrm{~kg}$ for the UK (Langley et al., 2010 [2]), $72 \mathrm{~kg}$ in the Netherlands (Westerhoven and Steenhuisen, 2010) [3] to 71-92 kg for Germany (BELV, 2012 [4]). However, a much larger value of $140 \mathrm{~kg} / \mathrm{head} /$ year is reported again for the UK by the Waste and Resources Action Programme (WRAP) (2009 [5]) (Figure 1). The former values are equivalent to a financial loss of $c a$. $€ 200-260$ per person per year. The surveys and statistics (Figure 1) include food waste from the food industry, private households as well as restaurants, canteens and both wholesalers and retailers; their relative contribution is shown Table 1. 


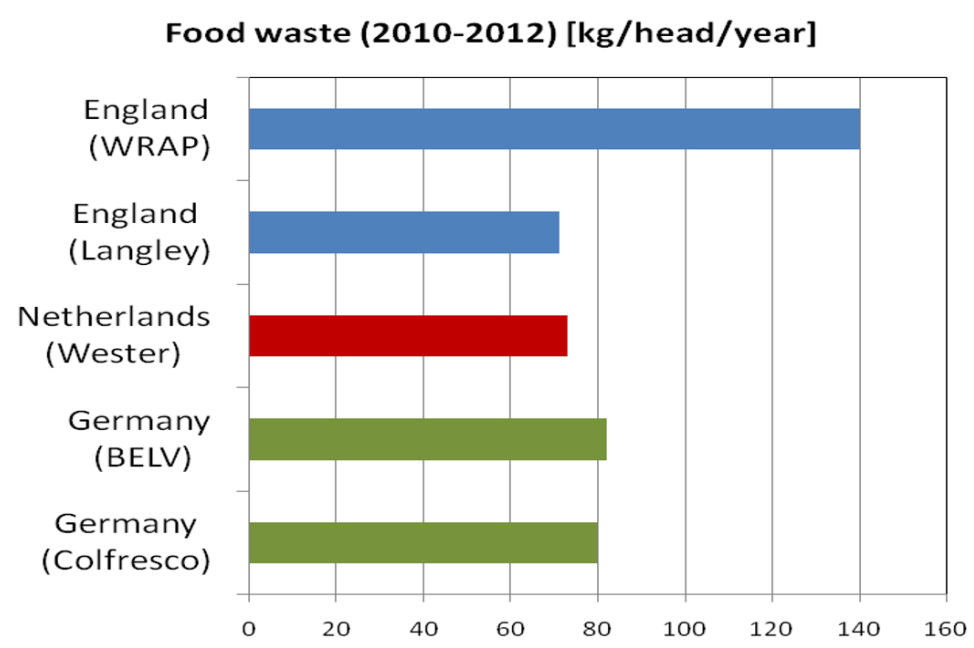

Figure 1. Food waste in Germany, England and the Netherlands (2010-2012).

Table 1. Sources of waste along the food chain in Germany (BELV, 2012 [4]).

\begin{tabular}{ccc}
\hline Source & Waste (Absolute Value in t/a) & Waste (Percentage) \\
\hline Private households & $6,670,000 \mathrm{t}$ & $61 \%$ \\
Canteens, restaurants & $1,900,000 \mathrm{t}$ & $17 \%$ \\
Industry & $1,850,000 \mathrm{t}$ & $17 \%$ \\
Trade-both wholesale and retail & $550,000 \mathrm{t}$ & $5 \%$ \\
Total waste & $11 \mathrm{mil} \mathrm{t}$ & $100 \%$ \\
\hline
\end{tabular}

\section{Sources of Food Waste-A Key to Identifying Solutions and Avoiding Waste}

Marks and Spencer's, one of the major UK retailers, analyzed (Hill, 2013 [6]) the sources of their fresh produce waste: The predominant source or site of their food waste of $c a .2$ million tonnes/year $(70 \%)$ was in the supply chain compared with relatively small losses of the actual produce (25\%) and $5 \%$ in the supermarket (Figure 2).
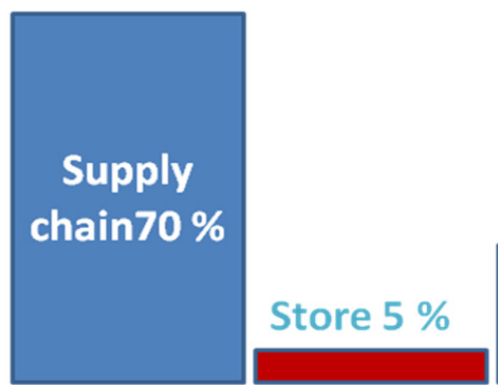

\section{Product \\ $25 \%$}

Figure 2. Sources of waste in the food supply chain (Hill, 2013 [6]).

In the US, food waste is reported to account for up to $c a$. $30 \%$ compared to $16 \%$ in Europe, where $54 \%$ of the $82 \mathrm{~kg}$ versus $44 \mathrm{~kg}$ comprise ca. $26 \mathrm{~kg}$ vegetables (Table 2) and ca. $18 \mathrm{~kg}$ fruit (Figure 3).

In the strive for waste avoidance strategies, Cofresco (2011) [7] and BELV (2012) [4] stated that respectively $59 \%$ and $65 \%$ of this overall food waste along the supply chain may be avoided. In the UK (WRAP, 2013) [5], 51\% (813,000 t) of the overall vegetable and salad waste (1.6 million tonnes) can be avoided as can $37 \%(340,000 \mathrm{t})$ of the fruit wasted annually in the UK $(910,000 \mathrm{t})$ (Table 3$)$. 
This gave rise to the "Fresh for Longer" campaign by WRAP, the film "Good food bad food" by Coline Serreau and a book and film in 2013 by Valentin Thurn entitled "Taste the waste". These three initiatives sparked public awareness and criticism of wasting fresh produce, thereby making it the challenge, task and responsibility of everyone involved in agriculture and the food supply chain.

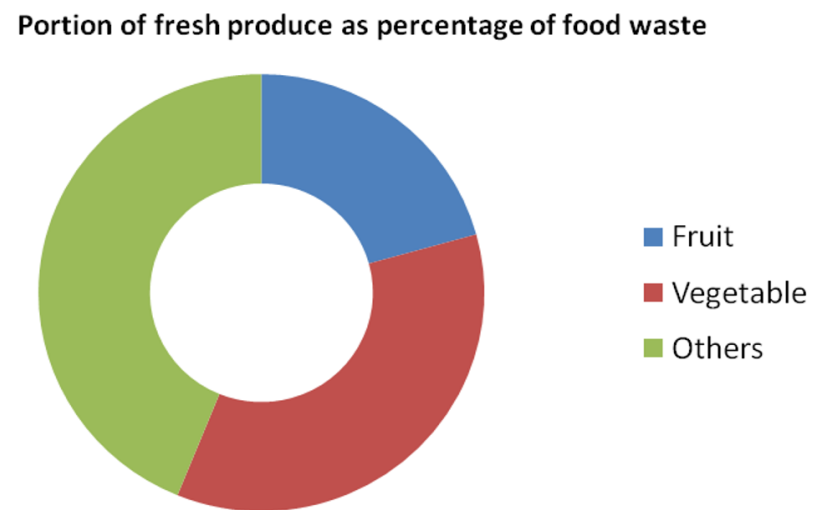

Figure 3. Proportion of perishable produce in food waste in Germany $(100 \%=82 \mathrm{~kg}$; BELV, 2012 [4]).

Table 2. Waste of perishable fresh fruit, vegetables \& salads and potatoes in the UK (WRAP, 2013 [8]).

\begin{tabular}{cccc}
\hline Commodity & $\begin{array}{c}\text { Waste (absolute } \\
\text { value } \\
\text { (tonnes/year) }\end{array}$ & $\begin{array}{c}\text { Waste that can be } \\
\text { avoided (percentage) }\end{array}$ & $\begin{array}{c}\text { Waste that can be } \\
\text { avoided (absolute in } \\
\text { tonnes/year) }\end{array}$ \\
\hline Vegetables and salads & $1,600,000 \mathrm{t}$ & $51 \%$ & $813,000 \mathrm{t}$ \\
Fresh fruit & $910,000 \mathrm{t}$ & $37 \%$ & $340,000 \mathrm{t}$ \\
Potato & $5,900,000 \mathrm{t}$ & $5 \%$ & $320,000 \mathrm{t}$ \\
Total waste & $2,510,000 \mathrm{t}$ & n.a. & $1,473,000 \mathrm{t}$ \\
\hline
\end{tabular}

Table 3. Countermeasures against waste of perishable fresh food at the farm level.

\begin{tabular}{cc}
\hline Countermeasure & Solution \\
\hline Fruit breeding for low ethylene & Ethylene insensitive breeding lines (apple and tomato) \\
\hline Blocking ethylene receptors & 1-MCP treatment before/after harvest \\
\hline Cooling & Retards fruit ripening and ethylene emission \\
\hline Replace combustion engines & use hand or electric fork lifts, vents etc. \\
\hline Vents & Introduce fresh ambient air \\
\hline Ethylene separator & Ethylene scrubber in fruit (CA/ULO) stores \\
\hline Ethylene absorber & Sachets (Ryan /Sensitech Co.USA) or strips (It's Fresh \\
UK) in the punnet
\end{tabular}




\section{Five Approaches to Reduce Waste in the Field}

In Europe, $c a .1 / 3$ of the vegetable crop remains in the field (Figure 4) due to either not meeting marketing standards or insufficient market demand, as known from waste assessment during carbon footprint studies [9]. Ethylene plays a key role; its accumulation may lead to decay or overripe fruit and vegetables. Ethylene-sensitive climacteric fruits score high in the waste reports, e.g., of WRAP (2013) of 1.4 million bananas and 1.5 million tomatoes wasted daily nationwide in the UK despite a $6 \%$ decrease in the overall food waste in the last few years.

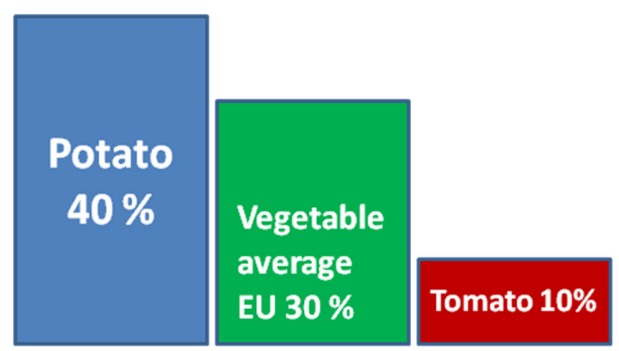

Figure 4. Waste left in the field.

\subsection{Inhibitors of Ethylene Biosynthesis}

In the field, AVG (aminoethoxyvinyl-glycine-"Retain ${ }^{\circledR} "$, an inhibitor of ethylene synthesis), viz. inhibition of formation of ACC from SAM via ACC synthase, can reduce pre-harvest fruit drop in affected climacteric pome fruits such as apples and pears, thereby preventing fresh produce waste. However, registration is not expected in Europe.

\subsection{Blocking the Ethylene Receptors to Extend Shelf-Life}

Harvista: 1-MCP (1- methylcyclopropene; "Smartfresh ${ }^{\circledR}$ "), used so far in Europe only after harvest,

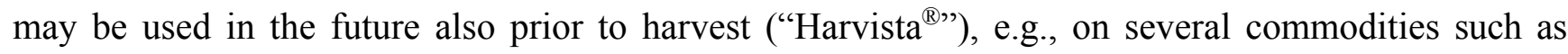
apples and tomatoes to delay ripening via blocking the ethylene receptors and the ethylene-induced ripening cascade (Sisler and Serek, 1997 [10]).

\subsection{Potato and Onion Storage with the Addition of Ethylene}

In contrast to the majority of perishable fruit and vegetables (and flowers), onion (Bufler, 2009 [11] and potato (Rylski et al., 1974 [12] can often be successfully stored with ca. 10 ppm ethylene (ca. 5-15 ppm $\mathrm{C}_{2} \mathrm{H}_{4}$ for onion, ca. 5-50 ppm $\mathrm{C}_{2} \mathrm{H}_{4}$ for potato) with a recent technology ("BioFresh", and "Restrain"); in this case, ethylene in the lower ppm range suppresses germination of the eyes on these tubers. Generally, the optimum 1-MCP or ethylene concentration depends on the commodity, variety, ripening stage, storage conditions (temperature, $\mathrm{CO}_{2}$ ) and intended storage period. 


\subsection{Waste in the Field not Meeting Class I Marketing Standards}

In the field, fruit and vegetables are already rejected, because they do not meet class 1 EU marketing standards, like VO EU No. 543/2011 for apple, and may go to waste, unless the rejects become useful and economic for processing, e.g., for juice, sauce, vinegar, cake or distilling, etc.

\subsection{Whole Crop Purchase (WCP)}

Instigated by the class I marketing debate, a new concept of whole crop purchase (WCP) is being developed (Table 3), but it is suitable largely for vertically integrated enterprises, who can make proper use of class II produce or even of industrial grade produce.

The described ethylene-related technologies are readily available to control ripening. There are, however, very few exceptions such as It's Fresh strips for apple or 1-MCP for cv. "Braeburn" apple, which can develop internal (Braeburn) browning (Mattheis and Rudell, 2008 [13]). If harvest was inadequately timed (too early) in apple or ripening after fruit storage lacking, 1-MCP can adversely affect ripening including firmness, color and aroma formation [13]. "BioFresh"/"Restrain" may induce off-flavor in three potato varieties [12].

\section{Four Approaches to Alleviate Waste in the Food Chain-Transport/Wholesale}

Climacteric fruit are obviously the first major source of ethylene in all compartments along the food chain from wholesale market, receiving area, storage and display shelves in the supermarket. Since ethylene diffuses freely, considerable amounts of ethylene may also remain in these compartments depending on the amount, stage of ripeness and type of fruit and length of storage where climacteric fruit had been stored previously, even when they are emptied. In Australia, as much as $280 \mathrm{ppb}$ ethylene has been found in an empty storage room, which previously held ripe (climacteric) avocado fruit (Wills et al., 2000 [14]) long before the food waste debate in Europe. The new generation of portable instruments enables continuous in-situ determination of ethylene, where it is produced, during long haul of fruit, vegetables and flowers on trucks or ships or by exhaust fumes from internal combustion engines.

However, the second considerable source of ethylene may be from internal combustion engines, where substantial movements of tractors, gas or fuel powered forklifts, trucks and their cooling units, which often continue running while the truck's engine is off, occur in the vicinity of the fruit and vegetables. Quantities of ethylene in three Australian RDCs investigated by Wills et al. (2000) [14] were described as "never low" as a basis to identify hot spots of ethylene accumulation in the food chain.

\subsection{Cooling}

In the food chain, continuous cooling controls fruit ripening and ethylene synthesis, as the simplest and most efficient approach. 


\subsection{Venting}

Similarly, vents can prevent ethylene accumulation around the sensitive fruit and vegetables by introducing fresh ambient air with only $1-6 \mathrm{ppb} \mathrm{C}_{2} \mathrm{H}_{4}$ on long haul ships, or by the use of ethylene absorbers or packages with different resistance to the four relevant gases.

\subsection{Inhibitor of Ethylene Receptors}

1-MCP (1-methylcyclopropene; "Smartfresh ${ }^{\circledR}$ "; Table 3) can be used on several commodities such as apples or tomatoes to delay ripening via blocking the ethylene receptors and the ethylene-induced ripening cascade (Sisler and Serek 1997 [10]).

\subsection{Ethylene Absorbers and Scrubbers}

Ethylene absorbers sachets (Sensitech Ryan Co, Beverly, MA, USA) and clay mineral coated strips (It's Fresh, UK) are both available for bulk or retail application e.g., of kaki (Figure S3) and strawberries (Figure S4) and many other fruits. For the absorbing systems to be effective, the commodity is best packaged either in modified atmosphere (MA) or with the absorbers already at the packhouse, to be re-used by the consumer. They may lose some of their benefits once the package is opened by the consumer, unless reseal able bags are used such as, e.g., "Peakfresh", where clay mineral is integrated in the plastic pack, which then becomes opaque (Figure S5), as a sustainable strategy.

\section{Eight Approaches to Alleviate Waste at the Retail and Consumer Level}

\subsection{Supermarket}

Fresh produce such as fruit and vegetables are sometimes wasted, when they remain un-sold in the store on Saturday evening, particularly in countries where supermarkets close over weekends such as Austria, Germany and Switzerland.

\subsection{Canteens and Refectories}

Fresh produce such as fruit and vegetables are similarly wasted in canteens at the end of the week (Friday or Saturday) before they close for the weekend, or bank holidays.

\subsection{Consumer}

Fresh produce often decays and is wasted, when over-bought and expected visitors did not turn up or over a weekend or bank holiday and it remains un-eaten; private households are responsible for the largest portion of food waste (Figure 1: 61\%).

\subsection{Dedicated Recipes for Over-ripe Fruit}

Optimization of fruit and vegetable storage and private shopping behavior at home; recipes utilizing ripening perishable food could be a simple but effective answer. 


\section{5. "Display until" or "Sell-by" Date}

In the UK, some of this food waste may also be due to "Display until" and "Sell by" date on packed food items in the supermarkets (Supplement File, Figure S1), which lead to disposal of possibly still edible fruit. This practice is currently disputed and countermeasures are being discussed and enforced in both the UK and Germany (Table 4).

\subsection{Sales of Class II Fruit}

Since September 2013, Austrian Billa, Merkur and Adeg sell "Wunderlinge" ("odds") (Figure S6), i.e., class 2 apple fruit, carrots and potatoes at a $25 \%$ lower price to reduce waste of otherwise industrial or wasted fruit at the producer level and support and encourage regional produce (Blanke and Burdick, 2005 [15]); REWE sells "Kleine Äpfel" ("small apples") in Germany (Supplemental Figure S7).

Concomitantly, Coop in Switzerland started selling class II fruit and vegetables as "Ünique". The great success of this Coop sustainability initiative led to an extension to a fair range of commodities such as bent-cucumbers, carrots, sweet pepper, asparagus, kiwi, lemon, orange, potato and in 2013, hail apricots from the Wallis region in Switzerland (Figures S8 and S9) with their own class II quality standards [16].

\subsection{Food Sharing}

Food sharing (https://foodsharing.de) is an advent of the social media founded by the film editor Valentin Thurn. In contrast to "Die Tafel" (Chapter 6.8), "Foodsharing" [17] provides the IT, i.e., the Internet platform for private households in five districts in Germany (Hamburg, Berlin, Cologne, Munich and Frankfurt) and Austria's Capital Vienna. Private persons, once registered, can use the "Foodsharing" platform to offer their left-over perishables, e.g., before their holidays or after a weekend, and arrange for regional collection, which sometimes ends up in joint cooking of meals as a positive social side-effect.

Table 4. Sources of food waste and corrective actions at the retail-consumer interface.

\begin{tabular}{ccc}
\hline Causes & Countermeasure & Corrective Actions to be Taken \\
\hline $\begin{array}{c}\text { EU marketing } \\
\text { standards-class I }\end{array}$ & $\begin{array}{c}\text { Whole crops purchase } \\
\text { (WCP) }\end{array}$ & $\begin{array}{c}\text { Deliberate sale of } \\
\text { class II fruit }\end{array}$ \\
\cline { 2 - 3 } $\begin{array}{c}\text { "Display until" date } \\
\text { (UK) }\end{array}$ & Abandon this practice & "Purchase of the whole crop of the tree" or from the field \\
\hline Food waste & $\begin{array}{c}\text { Recipes including } \\
\text { (over-) ripe fruit }\end{array}$ & Less waste at super-market level \\
\hline $\begin{array}{c}\text { Food waste in } \\
\text { private households }\end{array}$ & Food sharing & Recipes including very ripe fruit \\
\hline $\begin{array}{c}\text { Food Waste at } \\
\text { wholesale/retail }\end{array}$ & Die Tafel (Germany) & $\begin{array}{c}\text { Left-over perishables in private households } \\
\text { are offered for collection on social media }\end{array}$ \\
\hline
\end{tabular}




\section{8. 'Die Tafel' in Germany versus 'Food Banks' in the UK}

"Die Tafel" (www.tafel.de) [18] successfully collects left-over perishable produce like fruit and vegetables and other food with their own volunteers in $c a .1000$ nation-wide locations from canteens, restaurants, supermarkets, catering enterprises and airlines, etc., for free distribution in Germany to those in need (1.5 mil people in the last 20 years in Germany) thereby greatly reducing waste of perishable food, whereas the "food banks" in the UK help collect un-wanted, over-bought quantities of non-perishable food.

\section{Successful Countermeasures in Western Europe}

The waste of perishable food discussion peaked around 2012 with focused media attention in Germany, UK, Switzerland and Austria. As a consequence, UK supermarkets started discussing the "display before" label and to withdraw multi-pack offers ("Two raspberry punnets for the price of one"), and a few German, Austrian and Swiss supermarkets started to sell class II produce on a small scale. Coop (Switzerland) had to restrict the number of outlets with "Ünique" produce, since demand exceeded offers. Coop sold $180 \mathrm{t}$ class II carrots, $36 \mathrm{t}$ pears in 2014 and $122 \mathrm{t}$ apricots damaged in the hailstorm 2013 (CS 9) [17], which would have otherwise gone to waste in Switzerland.

Food sharing [16] is a new concept mostly for the younger generation, where social media is popular, and has gained popularity in a very short time. 'Die Tafel' [18] successfully collected left-over perishable produce in $c a .1000$ nation-wide locations for 1.5 mil people in need in the last 20 years in Germany, thereby greatly reducing waste of perishable food. Overall, fruit and vegetable consumption in Europe currently decreases by $c a$. 2\% annually, which is partly attributed to more considerate and conservative shopping, thereby reducing food waste. In the UK, WRAP (2013 [8]) similarly reported a $6 \%$ decrease in the overall food waste in the last six years and aims at a $50 \%$ reduction of the avoidable waste, as stated in Table 2, by 2025.

Compared to the $21 \%$ decrease in avoidable household waste in the UK (Table 2) over the last six years (2007-2013), this drop was surprisingly only as little as $4 \%$ in vegetables and salads (from $851,600 \mathrm{t}$ to $813,600 \mathrm{t}$ ), but as much as $26 \%$ with fresh fruit (WRAP, 2013 [8]).

\section{Conclusions}

There will still be a proportion of wastage of fresh perishable produce such as fruit and vegetables, due, e.g., to mold despite all our efforts and using some of the upcoming techniques. However, our task should be to reduce fresh produce wastage at all levels from field to fork and may be acknowledged as part of an already existing sustainability label [19] or part of the QRC code on the produce or shelf. The future will show how much each of the different approaches at the three levels can contribute to actually reducing fresh produce waste, but every attempt and idea is a much appreciated and valued effort to safeguard our natural resources including labor, water and land and contribute to reducing GHG emissions, e.g., by use of less nitrogen fertilizer as a source of $\mathrm{N}_{2} \mathrm{O}$. 


\section{Supplementary Materials}

Figure S1: Tomatoes in a UK high street store with both the "display until" and "best before" date in 2014.

Figure S2: Unnecessary exposure of perishable commodities (lettuce) to sun, freshly delivered lettuce in a med county store left out in the $\operatorname{sun}\left(30^{\circ} \mathrm{C}\right.$ at the time of the photo) where it is prone to wilt, which could simply be prevented by shading.

Figure S3: Kaki shipment with the Ryan ethylene sachets from Sensitech USA in a wholesale box.

Figure S4: Strawberry punnet with the ethylene absorber strip at the bottom from It's Fresh, UK; the pad is added at the pack house and remains active until the consumer's home.

Figure S5: Ethylene absorbing clay minerals integrated in the plastic bag by PeakFresh, Australia, which becomes opaque.

Figure S6: Uneven or odd-shaped fruit like apples and vegetables like carrots sold at a $25 \%$ discount price as "Wunderlinge-Vielfalt der Natur" in a Billa store, Austria ( ${ }^{\odot} \mathrm{A}$ Schroeckl).

Figure S7: Class II apples of the small-fruited cv. "Gala" as "Kleine Äpfel" in a REWE store in Germany.

Figure S8: Sale of class II bend cucumbers in a Co-OP store in Switzerland ( ${ }^{\circ}$ Ünique, Coop, Switzerland).

Figure S9: Sale of class II "Ünique" hail-hit apricots from the Swiss Wallis region in 2013 ( ${ }^{\circ}$ Coop Switzerland).

\section{Acknowledgements}

The author is grateful to Professor Daryl Joyce, Australia for the invitation to this concept paper and editors for editorial guidance, the two anonymous referees for their valued suggestions, Andrea Schroeckl, University of Graz for the photo of the "Wunderlinge" in Billa, Austria and David Cooke, St. Austell, UK for revising the English.

\section{Conflicts of Interest}

The author declares no conflict of interest.

\section{References}

1. Blanke, M.M. Perspectives of fruit research and apple orchard management in Germany in a changing climate. In Acta Horticulturae; Palmer, J., Ed.; ISBN 978-90-6605-531-5; ISHS: Korbeek-Lo, Belgium, 2007; Volume 772, pp. 441-447.

2. Langley, J. Food for Thought?-A UK pilot study testing a methodology for compositional domestic food waste analysis. Waste Manag. Res. 2010, 28, 220-227.

3. Van Westerhoven, M.; Steenhuisen, F. Bepaling Voedselverliezen bij Huishoudens en Bedrijfscatering in Nederland; CREM: Amsterdam, The Netherlands, 2010. (In Dutch)

4. BELV. Ermittlung der weggeworfenen Lebensmittel und Vorschläge zur Verminderung der Wegwerfrate bei Lebensmitteln in Deutschland; Institute für Abfallwirtschaft der Universitäten Stuttgart-Hohenheim und BoKu Wien: Stuttgart, Germany, 2012; p. 42. (In German) 
5. WRAP. Waste and Resources Action Programme, UK Government Watchdog on Waste Household Food and Drink Waste in the UK; Final Report 2009; WRAP: Banbury, Oxon, UK, 2009; ISBN: 1-84405-430-6.

6. Hill, R. Plan A: Product footprint. In Proceedings of the BSI Product Sustainability Conference, Drummond Gate, UK, 28 November 2013.

7. Cofresco Frischehalteprodukte Europa. Das Wegwerfen von Lebensmitteln-Einstellungen und Verhaltensmuster. Ergebnisse Deutschland. Save Food Studie. Available online: http://www. cofresco.de/pdf/Results_Save_Food_Study_Germany.pdf.011 (accessed on 10 March 2015).

8. WRAP. Waste and Resources Action Programme, UK Government Watchdog on Waste; WRAP: Banbury, Oxon, UK, 6 November 2013. Available online: http://www.wrap.org.uk/content/ use-your-loaf-and-save-billions (accessed on 30 March 2015).

9. Schaefer, F.; Blanke, M.M. Farming and marketing system affect carbon and water footprint of Hokaido pumpkin. J. Clean. Prod. 2012, 28, 113-119.

10. Sisler, E.C.; Serek, M. Inhibitors of ethylene responses in plants at the receptor level-recent developments. Physiol. Plant. 1997, 100, 577-582.

11. Bufler, G. Exogenous ethylene inhibits sprout growth in onion bulbs. Ann. Bot. 2009, 103, $23-28$.

12. Rylski, I.; Rappaort, L. Pratt, H.K. Dual effects of ethylene on potato tuber dormancy and sprout growth. Plant Physiol. 1974, 53, 658-662.

13. Mattheis, J.P.; Rudell, D.R. Diphenylamine metabolism in "Braeburn" apples stored under conditions conducive to the development of internal browning. J. Agric. Food Chem. 2008, 56, 3381-3385.

14. Wills, R.B.H.; Warton, M.A.; Ku, V.V.V. Ethylene levels associated with fruit and vegetables during marketing. Aust. J. Exp. Agric. 2000, 40, 485-470.

15. Blanke, M.M.; Burdick, B. Food (miles) for thought-primary energy balance for locally-grown versus imported apple fruit. Environ. Sci. Pollut. Res.-ESPR 2005, 12, 125-127.

16. Coop vergrössert Ünique Sortiment. Coop Suisse 2015. Available online: http://www.coop.ch/pb/ site/search/search/2057/Lde/index.html?qs =\%C3\%BCnique \&fr=coop2012\&search=search \&back end=backend_coop2012\&la $=$ de\&_sid=665f691e-1a51-45ed-9aa5-3938c44b8f68 (accessed on 25 June 2015).

17. Foodsharing, 2015. Available online: https://foodsharing.de (accessed on 2 April 2015) (In German).

18. Die Tafel. Available online: www.tafel.de (accessed on 3 February 2015) (In German).

19. Schaefer, F.; Blanke, M.M. Opportunities and challenges for carbon footprint, climate or $\mathrm{CO}_{2}$ labels for horticultural products [-Nachhaltige Kennzeichnung klimafreundlicher Lebensmittel]. Erwerbs-Obstbau 2014, 56, 73-80.

(C) 2015 by the author; unless otherwise stated; licensee MDPI, Basel, Switzerland. This article is an open access article distributed under the terms and conditions of the Creative Commons Attribution license (http://creativecommons.org/licenses/by/4.0/). 